\title{
Genetic factors in pathogenesis of diabetes mellitus after kidney transplantation
}

\author{
This article was published in the following Dove Press journal: \\ Therapeutics and Clinical Risk Management \\ 6 April 2017 \\ Number of times this article has been viewed
}

\author{
Maciej Tarnowski' \\ Sylwia Słuczanowska- \\ Głabowska' \\ Andrzej Pawlik' \\ Małgorzata Mazurek- \\ Mochol $^{2}$ \\ Elżbieta Dembowska² \\ 'Department of Physiology, \\ ${ }^{2}$ Department of Periodontology, \\ Pomeranian Medical University, \\ Szczecin, Poland
}

Correspondence: Maciej Tarnowski Department of Physiology, Pomeranian Medical University, Powstańców

Wielkopolskich 72, 70-III

Szczecin, Poland

Tel +48 9 I 466 I6II

Fax +48 9| 466 I6I2

Email maciejt@pum.edu.pl

\begin{abstract}
Posttransplant diabetes mellitus (PTDM) is one of the major metabolic complications after transplantation of solid organs including the kidney. This type of diabetes mellitus affects allograft survival, cardiovascular complications and overall patient survival. The modifiable risk factors that contribute to PTDM include obesity, some viral infections (eg, hepatitis C virus, cytomegalovirus) and especially immunosuppressive drugs including corticosteroids, tacrolimus, cyclosporine and sirolimus. Currently, predisposing genetic factors have been considered important in PTDM development. The commonly evaluated genetic determinants include genes encoding transcription factors, cytokines, chemokines, adipokines, ionic channels, glucose transporters, cytochrome P450 enzymes and other enzymes metabolizing drugs, drug transporters. Unfortunately, the results of studies are inconclusive and differ between populations. There is a need for large genome-wide association study to identify the genetic risk factors associated with PTDM development.
\end{abstract}

Keywords: diabetes mellitus, kidney, transplantation, gene polymorphism, SNP

\section{Introduction}

Posttransplant diabetes mellitus (PTDM) is one of the major metabolic complications after transplantation of solid organs including the kidney. This type of diabetes mellitus affects allograft survival and also cardiovascular complications and overall patient survival. The incidence of PTDM after kidney transplantation varies from 5.5\% to $60.2 \%$ of recipients. ${ }^{1,2}$ The occurrence of PTDM in the early posttransplant period suggests that the risk factors exist or develop at the time of or prior to transplantation. The PTDM risk factors are divided into 2 groups: modifiable and non-modifiable. Common modifiable risk factors include obesity, sedentary lifestyle, other metabolic syndromes associated with obesity, some viral infections (eg, hepatitis $\mathrm{C}$ virus, cytomegalovirus), drugs used in posttransplantation therapy including corticosteroids, which are a mainstay of immunosuppression after transplantation of solid organs, and other immunosuppressive agents (eg, tacrolimus, cyclosporine and sirolimus). ${ }^{3-9}$ The non-modifiable risk factors are advanced age, black race including African, Hispanic or South Asian descent, genetic background (eg, HLA B27 phenotype), previously diagnosed glucose intolerance and adult polycystic kidney disease. ${ }^{3,10-13}$ All of these risk factors contribute to beta-cell dysfunction in the pancreas prior to or after kidney transplantation. Previous studies suggest that genetic background plays an important role in the pathogenesis of PTDM. Moreover, the differences between populations in prevalence of PTDM were observed. The studies suggest that African, Hispanic and South Asian have higher incidence of PTDM., ${ }^{30-13}$

Solid organ transplantation (including kidney) requires the use of immunosuppressive drugs such as steroids and calcineurin inhibitors (CNIs) to maintain graft function. 
Unfortunately, these drugs contribute to the development of PTDM. ${ }^{3}$ The corticosteroids are well documented to cause hyperglycemia by inducing insulin resistance, increasing hepatic gluconeogenesis and stimulating appetite resulting in increased weight. The impact of corticosteroids is dose dependent. For example, a low dose of prednisone ( $5 \mathrm{mg}$ /day) for 5 years after kidney transplantation minimally impacted the incidence of PTDM. ${ }^{14-16}$ CNIs, such as cyclosporine and tacrolimus, also are diabetogenic. Cyclosporine increases the synthesis of polyamines, which regulate the function of pancreatic beta cells, inhibiting insulin secretion. ${ }^{17}$ The diabetogenic effect of tacrolimus is mainly caused by impaired insulin secretion by pancreatic beta cells and beta-cell toxicity. ${ }^{17-19}$ Tacrolimus induces beta-cell damage through induction of beta-cell apoptosis. Cyclosporine and tacrolimus can also increase insulin resistance by inhibiting the glucose transporter GLUT4, which leads to hyperglycemia. ${ }^{20}$ Tacrolimus also reduces glucokinase activity and suppresses insulin release by pancreatic islets. Both cyclosporine A and tacrolimus reduce insulin release, increase insulin resistance and reduce insulin gene expression, which lead to the development of PTDM. ${ }^{7,8,17,21}$ Both insulin secretion and insulin tissue action are decreased in PTDM. Hyperglycemia increases inflammatory reaction and expression of alloantigens as well as activates endothelial cells and the migration and adhesion of leucocytes. These factors induce an increase in circulating inflammatory mediators, which can contribute to transplant rejection. Hyperglycemia can also influence drug action including cyclosporine, which causes nephrotoxicity. ${ }^{22,23}$ In the end, PTDM contributes to cardiovascular complications and frequent inflammatory complications, which lead to a shortened lifespan. ${ }^{24,25}$ Therefore, it is important to minimize the incidence and impact of PTDM through pretransplant and posttransplant screening to identify patients with risk factors and improve the modified immunosuppressive regiments during and after transplantation coupled with glucoselowering therapies with insulin or oral hypoglycemic agents. The efforts of researchers are directed on identifying genetic determinants to predict an increased probability of PTDM.

\section{Genetic polymorphisms and risk of diabetes mellitus}

Many studies have investigated the genetic polymorphisms associated with increased risk of type 2 diabetes mellitus (T2DM). The commonly evaluated genetic determinants include genes encoding transcription factors and inflammation-associated genes. The gene products are mostly involved in beta-cell proliferation and apoptosis. However, the results obtained from evaluation of specific gene polymorphisms are inconclusive. The selected genetic observations are presented in Table 1.

One of the most intensively studied genes is TCF7L2, which was initially shown to be significantly associated with type 2 diabetes by genome-wide association study

Table I Results and statistical power for selected studies of associations between genetic polymorphisms and PTDM

\begin{tabular}{|c|c|c|c|c|c|c|c|c|}
\hline \multirow[t]{2}{*}{ Gene } & \multirow[t]{2}{*}{ Study } & \multirow[t]{2}{*}{ Association } & \multirow[t]{2}{*}{ MAF (\%) } & \multicolumn{3}{|c|}{ Number of patients } & \multicolumn{2}{|c|}{$\begin{array}{l}\text { Power of the study (MDD) a for PTDM } \\
\text { vs non-PTDM }\end{array}$} \\
\hline & & & & All & $\begin{array}{l}\text { Non- } \\
\text { PTDM } \\
\text { group } \\
\end{array}$ & $\begin{array}{l}\text { PTDM } \\
\text { group }\end{array}$ & $\begin{array}{l}\text { OR when MAF is } \\
\text { lower in PTDM vs } \\
\text { non-PTDM group }\end{array}$ & $\begin{array}{l}\text { OR when MAF is } \\
\text { higher in PTDM vs } \\
\text { non-PTDM group }\end{array}$ \\
\hline \multirow[t]{5}{*}{ TCF7L2 } & Kang et $\mathrm{al}^{28}$ & Yes & 2 & 511 & 392 & 119 & - & 3.073 \\
\hline & Kurzawski et $\mathrm{a}^{20}$ & Yes & 6 & 234 & 168 & 66 & 0.027 & 2.779 \\
\hline & Ghisdal et $\mathrm{al}^{29}$ & Yes & 13 & $\mathrm{I}, 034$ & 958 & 118 & 0.483 & $\mathrm{I} .70 \mathrm{I}$ \\
\hline & Yang et $\mathrm{a}^{32}$ & No & 21 & 303 & 170 & 133 & 0.520 & 1.717 \\
\hline & Khan et $\mathrm{al}^{30}$ & Yes & 25 & 140 & 98 & 42 & 0.335 & 2.249 \\
\hline \multirow[t]{2}{*}{ SLC30A8 } & Khan et $\mathrm{a}^{30}$ & Yes & 23 & 140 & 98 & 42 & 0.314 & 2.282 \\
\hline & Kang et $\mathrm{al}^{57}$ & Yes & 39 & 624 & 450 & 174 & 0.682 & 1.440 \\
\hline NFATC4 & Chen et $\mathrm{al}^{36}$ & Yes & 4 & 319 & 157 & 162 & 0.087 & 2.710 \\
\hline HNF-4A & Yang et $\mathrm{al}^{32}$ & Yes & 48 & 303 & 170 & 133 & 0.618 & 1.608 \\
\hline IRS-I & Yang et $\mathrm{al}^{32}$ & Yes & 2 & 158 & 170 & 133 & - & 3.416 \\
\hline \multirow[t]{3}{*}{ IL-6 } & Bamoulid et a ${ }^{37}$ & Yes & 13 & 349 & 290 & 59 & 0.301 & 2.109 \\
\hline & Babel et $\mathrm{al}^{39}$ & No & 43 & 275 & 221 & 54 & 0.516 & $1.87 \mid$ \\
\hline & Weng et $\mathrm{al}^{40}$ & Yes & 0.4 & 278 & 251 & 27 & - & 19.619 \\
\hline IL- 10 & Babel et al ${ }^{39}$ & No & 34 & 256 & 205 & 51 & $0.47 I$ & 1.917 \\
\hline TGF- $\beta$ & Babel et $\mathrm{a}^{39}$ & No & 27 & 276 & 219 & 57 & 0.452 & 1.899 \\
\hline TNF- $\alpha$ & Babel et a $\left.\right|^{39}$ & No & 13 & 273 & 220 & 53 & 0.256 & 2.233 \\
\hline TNF- $\alpha$ & Kao et $\mathrm{al}^{49}$ & No & 2 & 314 & 241 & 73 & - & 3.987 \\
\hline IL-28B & Duca et $\mathrm{al}^{4 !}$ & Yes & 39 & 99 & 71 & 28 & 0.338 & 2.564 \\
\hline
\end{tabular}


Table I (Continued)

\begin{tabular}{|c|c|c|c|c|c|c|c|c|}
\hline \multirow[t]{2}{*}{ Gene } & \multirow[t]{2}{*}{ Study } & \multirow[t]{2}{*}{ Association } & \multirow[t]{2}{*}{ MAF (\%) } & \multicolumn{3}{|c|}{ Number of patients } & \multicolumn{2}{|c|}{$\begin{array}{l}\text { Power of the study (MDD) }{ }^{a} \text { for PTDM } \\
\text { vs non-PTDM }\end{array}$} \\
\hline & & & & All & $\begin{array}{l}\text { Non- } \\
\text { PTDM } \\
\text { group }\end{array}$ & $\begin{array}{l}\text { PTDM } \\
\text { group }\end{array}$ & $\begin{array}{l}\text { OR when MAF is } \\
\text { lower in PTDM vs } \\
\text { non-PTDM group }\end{array}$ & $\begin{array}{l}\text { OR when MAF is } \\
\text { higher in PTDM vs } \\
\text { non-PTDM group }\end{array}$ \\
\hline & Veldt et $\mathrm{al}^{42}$ & Yes & 34 & 221 & 152 & 69 & 0.503 & 1.833 \\
\hline IL-2 & Kim et al ${ }^{43}$ & Yes & 51 & 306 & 253 & 53 & 0.532 & 1.893 \\
\hline$I L-7 R$ & Kim et $\mathrm{al}^{43}$ & Yes & 57 & 306 & 253 & 53 & 0.537 & 1.935 \\
\hline$I L-I 7 R$ & Kim et $\mathrm{al}^{43}$ & Yes & 59 & 306 & 253 & 53 & 0.537 & 1.955 \\
\hline$I L-I 7 R B$ & Kim et al ${ }^{43}$ & Yes & 46 & 306 & 253 & 53 & 0.524 & $1.87 \mid$ \\
\hline \multirow[t]{3}{*}{ CCL5 } & Jeong et $\mathrm{al}^{44}$ & Yes & 30 & 311 & 255 & 56 & 0.474 & 1.866 \\
\hline & Nicoletto et al ${ }^{45}$ & No & 14 & 270 & 187 & 83 & 0.371 & 1.987 \\
\hline & Dabrowska-Zamojcin et al ${ }^{46}$ & No & 24 & 315 & 272 & 43 & 0.379 & 2.054 \\
\hline CCL2 & Dabrowska-Zamojcin et $\mathrm{al}^{46}$ & Yes & 31 & 315 & 272 & 43 & 0.431 & 1.993 \\
\hline IL-I $7 F$ & Romanowski et al ${ }^{47}$ & Yes & 3 & 169 & 146 & 23 & - & 6.192 \\
\hline$I L-I 7 F$ & Romanowski et $\mathrm{al}^{47}$ & No & 9 & 169 & 146 & 23 & - & 3.564 \\
\hline IL-I $7 A$ & Romanowski et al ${ }^{47}$ & No & 35 & 169 & 146 & 23 & 0.311 & 2.556 \\
\hline IFN- $\gamma$ & Babel et $\mathrm{al}^{39}$ & Yes & 28 & 278 & 221 & 54 & 0.446 & 1.919 \\
\hline GPXI & Dutkiewicz et al $\left.\right|^{50}$ & Yes & 32 & 159 & 138 & 21 & 0.265 & 2.677 \\
\hline SODI & Dutkiewicz et al $\left.\right|^{50}$ & No & 49 & 159 & 138 & 21 & 0.351 & 2.793 \\
\hline SOD2 & Dutkiewicz et $\mathrm{al}^{50}$ & No & 5 & 159 & 138 & 21 & - & 4.590 \\
\hline \multirow[t]{2}{*}{ PPAR $\alpha$} & Elens et $\mathrm{al}^{53}$ & Yes & 25 & 101 & 76 & 9 & - & 4.562 \\
\hline & Kurzawski et a $\mathrm{a}^{54}$ & No & 21 & 241 & 177 & 64 & 0.410 & 1.955 \\
\hline \multirow[t]{2}{*}{$P 450$} & Elens et $\mathrm{al}^{53}$ & Yes & 8.1 & 101 & 76 & 9 & - & 6.455 \\
\hline & Kurzawski et a $\left.\right|^{54}$ & No & 26 & 241 & 177 & 64 & 0.454 & 1.890 \\
\hline P450 & Gervasini et $\mathrm{a}^{55}$ & Yes & 35 & 164 & 130 & 34 & 0.382 & 2.235 \\
\hline \multirow[t]{2}{*}{ KCNQ } & Yang et $\mathrm{al}^{32}$ & Yes & 36 & 303 & 170 & 133 & 0.597 & 1.615 \\
\hline & Kang et $\mathrm{al}^{57}$ & Yes & 62 & 624 & 589 & 145 & 0.685 & 1.495 \\
\hline \multirow[t]{2}{*}{ KCNJII } & Tavira et $\mathrm{al}^{61}$ & Yes & 35 & 50 & 405 & 40 & 0.449 & 1.984 \\
\hline & Parvizi et al ${ }^{62}$ & Yes & 37 & 120 & 60 & 60 & 0.423 & 2.148 \\
\hline \multirow[t]{2}{*}{ Angiotensin } & Lee et $\mathrm{a}^{66}$ & Yes & 10 & 302 & 253 & 49 & 0.158 & 2.428 \\
\hline & Özdemir et $\mathrm{a}^{67}$ & Yes & 33 & 50 & 27 & 23 & 0.183 & 3.414 \\
\hline CAPNIO & Kurzawski et al ${ }^{70}$ & Yes & 8 & 214 & 158 & 56 & 0.071 & 2.683 \\
\hline ENPPI & Szuszkiewicz et $\mathrm{al}^{71}$ & Yes & 13 & 115 & 79 & 36 & 0.091 & 2.848 \\
\hline eNOS & Ergün et $\mathrm{al}^{72}$ & Yes & 5 & 82 & 73 & 9 & - & 8.867 \\
\hline Adiponectin & Nicoletto et al ${ }^{45}$ & Yes & 28 & 270 & 187 & 83 & 0.511 & 1.767 \\
\hline PAI-I & Chang et $\mathrm{a}^{78}$ & Yes & 59 & 376 & 295 & 81 & 0.598 & 1.725 \\
\hline ADIPOQ & Kang et $\mathrm{al}^{74}$ & Yes & 30 & 575 & 421 & 154 & $0.64 I$ & 1.493 \\
\hline Adiponectin & Yu et $\mathrm{al}^{77}$ & Yes & 66 & 398 & 301 & 97 & 0.615 & 1.713 \\
\hline IGF2 & Vattam et $\mathrm{al}^{73}$ & Yes & 20 & 140 & 98 & 42 & 0.278 & 2.347 \\
\hline $\operatorname{PPAR} \gamma$ & Wang and Hudspeth ${ }^{79}$ & No & 11 & 123 & 72 & 51 & 0.107 & 2.788 \\
\hline$I N F \gamma$ & Wang and Hudspeth ${ }^{79}$ & No & 54 & 123 & 72 & 51 & 0.463 & 2.222 \\
\hline$I L-I \beta$ & Weng et $\mathrm{a}^{40}$ & No & 45 & 278 & 251 & 27 & 0.402 & 2.348 \\
\hline MTHFR & Weng et $\mathrm{a}^{40}$ & No & 25 & 278 & 251 & 27 & 0.273 & 2.402 \\
\hline VDR & Yao et $\mathrm{al}^{75}$ & Yes & 38 & 105 & 89 & 16 & 0.231 & 3.180 \\
\hline Leptin & Romanowski et $\mathrm{al}^{76}$ & Yes & 10 & 323 & 278 & 45 & 0.139 & 2.475 \\
\hline
\end{tabular}

Notes: aMDD: the true effect size measured as OR for minor vs major allele, which can be detected with $80 \%$ probability for the presented sample sizes and MAF (calculated with PS version 3.0.43 software); -, MAF in non-PTDM group was too low for the detection of even lower MAF in PTDM group with $80 \%$ statistical power.

Abbreviations: MAF, minor allele frequency; MDD, minimal detectable difference; OR, odds ratio; PTDM, posttransplant diabetes mellitus; PS, power and sample size calculation software.

(GWAS). ${ }^{26}$ Further studies implicated TCF7L2 rs7903146 (T allele) as the most common susceptible gene for T2DM. ${ }^{18}$ The TCF7L2 protein belongs to a T-cell transcription factor family that regulates cell proliferation and differentiation through the Wnt signaling pathway, which controls pancreas development and maturation as well as islet function.
The $\mathrm{T}$ allele has been associated with increased protein expression, impaired insulin secretion, impaired incretin effects and hepatic insulin resistance. ${ }^{19,27}$

The association between TCF7L2 rs7903146 singlenucleotide polymorphism (SNP) and PTDM is inconclusive. Studies on renal transplanted patients of Korean ${ }^{28}$ 
(511 patients) or white European ethnicity (total 1,320 patients) ${ }^{20,29}$ and 140 Indian Asians ${ }^{30}$ showed a significant association with the T allele; however, other studies did not support these data. ${ }^{31-33}$ Nonetheless, recent meta-analysis and further genotyping of 464 patients, mostly of white ethnicity treated with tacrolimus, revealed that the rs7903146 $\mathrm{T}$ variant confers a higher risk of PTDM in an allele dosedependent manner. ${ }^{34}$

Another gene associated with T2DM that contributes to PTDM pathogenesis is activating transcription factor 6 (ATF6). Fougeray et al did not find an association between 6 ATF6 SNPs and PTDM. However, the ATF6 rs2340721 SNP was associated with increased body weight and body mass index (BMI). ${ }^{35}$ Another transcription factor that was shown to be associated with PTDM is nuclear factor of activated T cells (NFAT) 4 (NFATC4). Chen et al showed that the NFATC4 T-T-T-T-G haplotype in Hispanic origin renal transplant patients had a reduced adjusted risk for PTDM. Specifically, the rs10141896 SNP T allele was associated with a lower cumulative incidence of PTDM. ${ }^{36}$

The second group of genes evaluated in the context of PTDM consists of interleukins (ILs) and inflammation-related factors. Both peripheral insulin action and insulin secretion appear to be affected in PTDM. ${ }^{36}$ Inflammatory chemokines and cytokines are involved in this process. ILs and other molecules are secreted by $\mathrm{T}$ cells and by stimulating the production of inflammatory cytokines (tumor necrosis factor [TNF]- $\alpha$, IL-1B and IL-6) mediate inflammation. There are several published studies of IL-6-174 SNP in relation to PTDM. ${ }^{37-39}$ Work by Bamoulid et al $^{37}$ involving 349 patients documents a statistically significant association between $\mathrm{GG}$ homozygotes and PTDM, and Weng et $\mathrm{al}^{40}$ showed that the IL-6 G/G genotype experienced a lower risk of developing PTDM in the Taiwanese population. Furthermore, there was a significant association between the $G$ allele and serum IL-6 levels. ${ }^{37}$ A study of 99 patients after liver transplantation showed that almost one-third (28 patients) developed PTDM. ${ }^{41}$ A statistically significant association was observed between $I L-28 B$ rs12979860 SNP and PTDM, ${ }^{41}$ which supported previous observations by Veldt et al in a similar study including 221 patients. $^{42}$

Another study that included 18 different SNPs in 10 different genes encoding ILs was performed by Kim et al. ${ }^{43}$ It was found that $61 \%$ of the evaluated SNPs (11/18) were significantly associated with PTDM in a Korean population of 306 renal transplant recipients. The evaluated SNPs include the following: $I L-1 B$ (rs3136558), $I L-2$ (rs2069762), $I L-4$ (rs2243250, rs2070874), $I L-7 R$ (rs1494558, rs2172749), $I L-17 R E$ (rs1124053), IL-17R (rs2229151, rs4819554) and $I L-17 R B$ (rs1043261, rs1025689). These genes were recently reported to be associated with type 1 diabetes mellitus and could be associated with the pathogenesis of PTDM in renal transplant recipients.

Another study from Korea ${ }^{44}$ shows that CCL5 gene polymorphisms, rs2107538, rs2280789 and rs3817655 were significantly associated with increased risk of PTDM. This association was confirmed in multiple logistic regression analysis. The TCA haplotype was associated with higher frequency of PTDM. ${ }^{44}$

A study of 270 Caucasian kidney transplant recipients did not confirm previous observations regarding CCL5 SNPs (rs2280789 and rs3817655), but researchers found an association between the $276 G / T$ adiponectin gene polymorphism (rs1501299) and PTDM. ${ }^{45}$ In addition to CCL5, other chemokines such as CCL2 or monocyte chemoattractant protein-1 were studied. A recent study by Dabrowska-Zamojcin et al on 315 patients of Caucasian origin showed that CCL2 rs1024611 polymorphism is an independent risk factor for posttransplant diabetes, but not rs2107538 of CCL5. ${ }^{46}$

A study by Romanowski et $\mathrm{al}^{47}$ conducted on 169 Caucasian patients (23 with PTDM) revealed an association between $I L-17 F$ SNP (rs763780) and PTDM. No significance was found for $I L-17 A$ polymorphism (rs2275913) and 2 other evaluated SNPs of $I L-17 F$ (rs11465553 and rs2397084). ${ }^{47}$

The genes involved in regulating lipid homeostasis and carbohydrate metabolism may also be involved in PTDM. Yang et al included 303 kidney transplant patients of Hispanic ethnicity and revealed that polymorphism of 2 alleles of the $H N F-4 A$ gene encoding transcription factor 14 (rs2144908 and rs1884614) and insulin receptor substrate 1 (rs1801278) are significantly associated with PTDM. ${ }^{32}$ Subsequent research by Chen et al revealed that the IRS-2 Gly1057Asp and IRS-1 Gly972Arg genotypes are not related to tacrolimus-induced PTDM in the Chinese population. ${ }^{48}$ Further analyses by Babel et al and Kao et al revealed no association between PTDM and the following polymorphisms: $-1082 \mathrm{IL}-10,-308 \mathrm{TNF}-\alpha$, TGF- $\beta 1$ (codon 10, 25), -174IL-6 and +874IFN- $\gamma$, and G-238A SNP. ${ }^{39,49}$

In a study involving 159 patients after kidney transplant, 21 developed PTDM, and a set of genes involved in oxidative stress (SOD1, SOD2, CAT and GPX1) was evaluated. Only $G P X 1$ SNP rs 1050450 was associated with increased risk of 
PTDM. ${ }^{50}$ The functional polymorphisms in this gene were shown to be associated with increased intima-media thickness of carotid arteries and risk of cardiovascular and peripheral vascular diseases in type 2 diabetic patients. ${ }^{51,52}$

Recent investigations have focused on SNPs of genes that play an important role in tacrolimus metabolism, such as peroxisome proliferator-activated receptor $\alpha(P P A R \alpha)$ and $\mathrm{P} 450$ oxidoreductase $(P O R)$, both of which are involved in control of energy uptake, lipid and carbohydrate metabolism. Elens et al observed an association between a coding POR variant (rs1057868) and 2 single-nucleotide substitutions in PPAR $\alpha$ (rs4823613 and rs4253728) and increased risk for PTDM. ${ }^{53}$ However, this result was not confirmed by Kurzawski et al in a subsequent study. ${ }^{54}$ Recently, Gervasini et al focused on cytochrome P450 enzymes in 164 patients and showed that a valine-to-methionine amino acid change in residue 433 of the $C Y P 4 F 2$ gene (rs2108622) is an independent risk factor of PTDM. ${ }^{55}$ The CYP4F2 gene encodes a $\omega$-hydroxylase that is involved in the synthesis of arachidonic acid active metabolites that regulate kidney function. In patients after heart transplantation, no associations were found between SNPs in cytochrome P450 3A isoenzymes and tacrolimusinduced PTDM. ${ }^{56}$

GWAS on an Asian population identified new loci associated with diabetes type II development. A study including 589 patients in a Korean population after kidney transplantation revealed 8 SNPs in 6 genes significantly associated with PTDM development with odds ratios ranging from 1.33 to $2.32 .{ }^{57}$ The 6 genes and 8 SNPs included TCF7L2 (rs7903146), SLC30A8 (rs13266634), HHEX(rs1111875, rs7923837 and rs5015480), CDKAL1 (rs10946398), CDKN2A/B (rs10811661), IGF2BP2 (rs4402960), FTO (rs8050136), WFS1 (rs734312), JAZF1 (rs864745), CDC123/CAMK1D (rs12779790), TSPAN8 (rs7961581), THADA (rs7578597), ADAMTS9 (rs4607103), NOTCH2 (rs1092391) and KCNQ1 (rs2237892). Interestingly, there was no association between the same SNPs and PTDM in a Polish population (235 patients). ${ }^{58}$ Similar negative results were obtained by Chakkera et $\mathrm{al}^{31}$ after analyzing similar sets of genes and SNPs in 91 patients.

Numerous studies have analyzed the association between $K C N J 11$ and $K C N Q 1$ gene polymorphisms and diabetes type 2 . The KCNJ11 gene is a member of the potassium channel gene family, which maps to chromosome 11p15.1. This gene encodes an inward-rectifier potassium ion channel (Kir6.2). Mutations in the $\mathrm{KCNJ11}$ gene are associated with defective insulin secretion and development of diabetes mellitus. ${ }^{59,60}$ The associations between $K C N J 11$ and $K C N Q 1$ gene polymorphisms and PTDM are not widely investigated.
Tavira et al examined the contribution of the rs5219 KCNJ11 gene polymorphism to PTDM after transplantation among patients treated with tacrolimus. ${ }^{61}$ The AA + AG genotypes were significantly associated with increased risk of PTDM. Parvizi et al observed an association between the KCNJ11 KK variant and an increased risk for PTDM. ${ }^{62}$ This study showed that polymorphisms in KCNJ11 might predispose the patients treated with tacrolimus to development of PTDM after liver transplantation. However, in the previously mentioned study by Kurzawski et al, ${ }^{58}$ there was no significant association between PTDM and rs5219 in KCNJ11.

Tavira et al performed an interesting study on Spanish patients who received a cadaveric kidney graft and developed PTDM in the first year posttransplant and on patients who remained nondiabetic. ${ }^{63}$ Three $K C N Q 1$ SNPs were genotyped. SNP rs2237895 (genotype CC) was associated with an increased risk for new-onset diabetes after transplantation (PTDM) in the studied population, independently of other risk factors such as BMI, recipient age, or tacrolimus dosage. Other $K C N Q 1$ variants were not associated with PTDM. Kang et al analyzed the association between PTDM development and KCNQ1 rs2237892. This polymorphism was significantly associated with PTDM in a cohort of renal allograft recipients in Korea. ${ }^{57}$

Insulin signaling pathways, blood flow, oxidative stress and adipogenesis may be affected by the renin-angiotensin system, which recently has attracted interest with regard to the pathogenesis of insulin resistance and diabetes mellitus in the general population. ${ }^{64,65}$ The study by Lee et al conducted on 302 Korean patients revealed an association between the AGT polymorphism (rs4762), but no association in the case of AGT SNP rs699 and angiotensinconverting enzyme rs4291. ${ }^{66}$ These results are in contrast to a previous relatively small study conducted on 50 patients of Turkish origin in which these SNPs were associated with PTDM. ${ }^{67}$

Among other genetic factors predisposing to PTDM, there is a polymorphism in the gene that encodes a nonlysosomal cysteine protease - calpain-10 (CAPN10). It is expressed in tissues important for the regulation of glucose homeostasis like fat, skeletal muscle, liver and pancreatic islets. ${ }^{68}$ What is more, $C A P N 10$ gene expression or mRNA stability may be affected by $C A P N 10{ }^{69}$ Kurzawski et al showed an interesting association "between PTDM and CAPN10 SNP-63 (rs5030952) polymorphism, as well as the 1-1-2 haplotype [derived from SNP-43 (rs3792267), SNP-19 (rs3842570) and SNP-63 (rs5030952)]". ${ }^{70}$ 
In a study of insulin resistance-related factors including 115 patients of mixed origin (white, Hispanic, black), Szuszkiewicz et al observed an association between the ENPP1 gene K121Q polymorphism and PTDM with an OR of 1.4. ${ }^{71}$ ENPP1 encodes a class 2 membrane glycoprotein that negatively influences sensitivity to insulin action by inhibiting insulin tyrosine-kinase receptor signaling. Another insulin-resistance gene that showed an association with PTDM is endothelial nitric oxide synthase (eNOS). Carriers of the intron 4 allele of $e N O S$ (4a allele) in a Turkish population of kidney allograft recipients treated with cyclosporine A had a higher risk of developing PTDM. ${ }^{72}$

Additional studies that also evaluated insulin-resistance genes focused on polymorphisms in IGF, leptin, adiponectin, adiponectin receptor, plasminogen activator-1 and vitamin D receptor genes. Significant associations were found in all of the cases. ${ }^{73-79}$ However, not all of them were confirmed in other studies. ${ }^{33,40}$

There is only one GWAS conducted on PTDM patients that investigated the clinical and genetic factors associated with PTDM in a relatively large, white renal transplant population. This study by McCaughan et al included 529 patients of which 57 developed PTDM. It was the first study to utilize an exploratory GWAS with confirmation by de novo genotyping. ${ }^{33}$ What is interesting and confusing at the same time is that the authors did not find any association between PTDM and previously described SNPs. However, they found 26 new SNP candidates out of which 8 were verified by genotyping. The 8 SNPs associated with PTDM were mostly involved in the PI3K-Akt signaling pathway. ${ }^{33}$

\section{Conclusion}

Solid organ transplantation may lead to serious metabolic complication occurring mainly due to immunosuppressive therapy known as PTDM. This disorder is of particular concern because it is associated with poor graft survival and increased risk of cardiovascular complications, chronic rejection and renal failure. ${ }^{47}$ The influence of PTDM on graft function and the circulatory system prompted a search for predictors of PTDM development. The identification of genetic factors predisposing to PTDM development may aid in deciding the proper immunosuppressive therapy in patients with increased risk of PTDM. The effective regimens of immunosuppressive therapy may help to prevent the development of PTDM, chronic allograft dysfunction and cardiovascular complications and improve graft survival. The patients who are carriers of some genetic variants should be considered as renal transplant recipients at higher risk of PTDM development, especially during therapy with immunosuppressive drugs with diabetogenic action such as tacrolimus. Their tacrolimus plasma levels and glycemia should be carefully monitored after transplantation. It would also be reasonable to avoid the use of other drugs with diabetogenic action. It can be speculated that the presence of some genetic variants with other independent risk factors of PTDM (higher BMI, older age) should be considered as the contraindication for treatment with strongly diabetogenic immunosuppressive regimens.

There is a need for large GWAS to identify the genetic risk factors associated with PTDM development. These studies should take into account candidate genes associated with diabetes type 2 and gene encoding enzymes involved in glucose metabolism and pancreatic beta cell function.

\section{Disclosure}

The authors report no conflicts of interest in this work.

\section{References}

1. Kamar N, Mariat C, Delahousse M, et al; Diapason Study Group. Diabetes mellitus after kidney transplantation: a French multicentre observational study. Nephrol Dial Transplant. 2007;22(7):1986-1993.

2. Park SC, Yoon YD, Jung HY, et al. Effect of transient post-transplantation hyperglycemia on the development of diabetes mellitus and transplantation outcomes in kidney transplant recipients. Transplant Proc. 2015;47(3):666-671.

3. Rodrigo E, Fernández-Fresnedo G, Valero R, et al. New-onset diabetes after kidney transplantation: risk factors. $J$ Am Soc Nephrol. 2006; 17(12 Suppl 3):S291-S295.

4. Israni AK, Snyder JJ, Skeans MA, Kasiske BL; PORT Investigators. Clinical diagnosis of metabolic syndrome: predicting new-onset diabetes, coronary heart disease, and allograft failure late after kidney transplant. Transpl Int. 2012;25(7):748-757.

5. Hjelmesaeth J, Sagedal S, Hartmann A, et al. Asymptomatic cytomegalovirus infection is associated with increased risk of new-onset diabetes mellitus and impaired insulin release after renal transplantation. Diabetologia. 2004;47(9):1550-1556.

6. van Raalte DH, Nofrate V, Bunck MC, et al. Acute and 2-week exposure to prednisolone impair different aspects of beta-cell function in healthy men. Eur J Endocrinol. 2010;162(4):729-735.

7. Ekberg H, Tedesco-Silva H, Demirbas A, et al; ELITE-Symphony Study. Reduced exposure to calcineurin inhibitors in renal transplantation. N Engl J Med. 2007;357(25):2562-2575.

8. Drachenberg CB, Klassen DK, Weir MR, et al. Islet cell damage associated with tacrolimus and cyclosporine: morphological features in pancreas allograft biopsies and clinical correlation. Transplantation. 1999;68(3):396-402.

9. Johnston O, Rose CL, Webster AC, Gill JS. Sirolimus is associated with new-onset diabetes in kidney transplant recipients. J Am Soc Nephrol. 2008;19(7):1411-1418.

10. Chakkera HA, Weil EJ, Swanson CM, et al. Pretransplant risk score for new-onset diabetes after kidney transplantation. Diabetes Care. 2011;34(10):2141-2145.

11. Gourishankar S, Jhangri GS, Tonelli M, Wales LH, Cockfield SM. Development of diabetes mellitus following kidney transplantation: a Canadian experience. Am J Transplant. 2004;4(11):1876-1882.

12. Hamer RA, Chow CL, Ong AC, McKane WS. Polycystic kidney disease is a risk factor for new-onset diabetes after transplantation. Transplantation. 2007;83(1):36-40. 
13. Yang B, Chen S, Yang G, Mei C, Ong A, Mao Z. New onset diabetes after kidney transplantation in patients with autosomal dominant polycystic kidney disease: systematic review protocol. BMJ Open. 2015;5(11):e008440.

14. Shivaswamy V, Boerner B, Larsen J. Post-transplant diabetes mellitus: causes, treatment, and impact on outcomes. Endocr Rev. 2016;37(1): 37-61.

15. Pirsch JD, Henning AK, First MR, et al. New-onset diabetes after transplantation: results from a double-blind early corticosteroid withdrawal trial. Am J Transplant. 2015;15(7):1982-1990.

16. Joss N, Staatz CE, Thomson AH, Jardine AG. Predictors of new onset diabetes after renal transplantation. Clin Transplant. 2007;21(1):136-143.

17. Yates CJ, Fourlanos S, Hjelmesaeth J, Colman PG, Cohney SJ. Newonset diabetes after kidney transplantation-changes and challenges. Am J Transplant. 2012;12(4):820-828.

18. Tong Y, Lin Y, Zhang Y, et al. Association between TCF7L2 gene polymorphisms and susceptibility to type 2 diabetes mellitus: a large Human Genome Epidemiology (HuGE) review and meta-analysis. BMC Med Genet. 2009;10:15.

19. Nam JH, Mun JI, Kim SI, et al. Beta-cell dysfunction rather than insulin resistance is the main contributing factor for the development of postrenal transplantation diabetes mellitus. Transplantation. 2001;71(10):1417-1423.

20. Kurzawski M, Dziewanowski K, Kędzierska K, Wajda A, Lapczuk J, Droździk M. Association of transcription factor 7-like 2 (TCF7L2) gene polymorphism with posttransplant diabetes mellitus in kidney transplant patients medicated with tacrolimus. Pharmacol Rep. 2011; 63(3):826-833.

21. Pereira MJ, Palming J, Rizell M, et al. Cyclosporine A and tacrolimus reduce the amount of GLUT4 at the cell surface in human adipocytes: increased endocytosis as a potential mechanism for the diabetogenic effects of immunosuppressive agents. J Clin Endocrinol Metab. 2014;99(10):E1885-E1894.

22. Hjelmesaeth J, Hartmann A, Leivestad T, et al. The impact of earlydiagnosed new-onset post-transplantation diabetes mellitus on survival and major cardiac events. Kidney Int. 2006;69(3):588-595.

23. Thomas MC, Mathew TH, Russ GR. Glycaemic control and graft loss following renal transplantation. Nephrol Dial Transplant. 2001;16(10): 1978-1982.

24. Ducloux D, Kazory A, Chalopin JM. Posttransplant diabetes mellitus and atherosclerotic events in renal transplant recipients: a prospective study. Transplantation. 2005;79(4):438-443.

25. Saleem TF, Cunningham KE, Hollenbeak CS, Alfrey EJ, Gabbay RA. Development of diabetes mellitus post-renal transplantation is associated with poor short-term clinical outcomes. Transplant Proc. 2003; 35(8):2916-2918.

26. Voight BF, Scott LJ, Steinthorsdottir V, et al; MAGIC investigators; GIANT Consortium. Twelve type 2 diabetes susceptibility loci identified through large-scale association analysis. Nat Genet. 2010;42(7): 579-589.

27. Lyssenko V, Lupi R, Marchetti P, et al. Mechanisms by which common variants in the TCF7L2 gene increase risk of type 2 diabetes. J Clin Invest. 2007;117(8):2155-2163.

28. Kang ES, Kim MS, Kim YS, et al. A variant of the transcription factor 7-like 2 (TCF7L2) gene and the risk of posttransplantation diabetes mellitus in renal allograft recipients. Diabetes Care. 2008;31(1):63-68.

29. Ghisdal L, Baron C, Le Meur Y, et al. TCF7L2 polymorphism associates with new-onset diabetes after transplantation. J Am Soc Nephrol. 2009;20(11):2459-2467.

30. Khan IA, Jahan P, Hasan Q, Rao P. Validation of the association of TCF7L2 and SLC30A8 gene polymorphisms with post-transplant diabetes mellitus in Asian Indian population. Intractable Rare Dis Res. 2015;4(2):87-92.

31. Chakkera HA, Hanson RL, Raza SM, et al. Pilot study: association of traditional and genetic risk factors and new-onset diabetes mellitus following kidney transplantation. Transplant Proc. 2009;41(10): 4172-4177.
32. Yang J, Hutchinson II, Shah T, Min DI. Genetic and clinical risk factors of new-onset diabetes after transplantation in Hispanic kidney transplant recipients. Transplantation. 2011;91(10):1114-1119.

33. McCaughan JA, McKnight AJ, Maxwell AP. Genetics of new-onset diabetes after transplantation. J Am Soc Nephrol. 2014;25(5):1037-1049.

34. Quaglia M, Terrazzino S, Musetti C, et al. The Role of TCF7L2 rs7903146 in diabetes after kidney transplant: results from a singlecenter cohort and meta-analysis of the literature. Transplantation. 2016;100(8):1750-1758.

35. Fougeray S, Loriot MA, Nicaud V, Legendre C, Thervet E, Pallet N. Increased body mass index after kidney transplantation in activating transcription factor 6 single polymorphism gene carriers. Transplant Proc. 2011;43(9):3418-3422.

36. Chen Y, Sampaio MS, Yang JW, Min D, Hutchinson IV. Genetic polymorphisms of the transcription factor NFATc4 and development of new-onset diabetes after transplantation in Hispanic kidney transplant recipients. Transplantation. 2012;93(3):325-330.

37. Bamoulid J, Courivaud C, Deschamps M, et al. IL-6 promoter polymorphism-174 is associated with new-onset diabetes after transplantation. J Am Soc Nephrol. 2006;17(8):2333-2340.

38. Sánchez-Velasco P, Rodrigo E, Fernández-Fresnedo G, et al. Influence of interleukin- 6 promoter polymorphism-174 g/c on kidney graft outcome. Transplant Proc. 2010;42(8):2854-2855.

39. Babel N, Cherepnev G, Kowalenko A, Horstrup J, Volk HD, Reinke P. Nonimmunologic complications and gene polymorphisms of immunoregulatory cytokines in long-term renal transplants. Kidney Int. 2004;66(1):428-432.

40. Weng SC, Shu KH, Tarng DC, et al. Gene polymorphisms are associated with posttransplantation diabetes mellitus among Taiwanese renal transplant recipients. Transplant Proc. 2012;44(3):667-671.

41. Duca AM, de la Fuente S, Citores MJ, et al. CC genotype at rs 12979860 of IL28B is associated with lower risk of new-onset diabetes after transplantation in adult patients with liver transplantation for hepatitis C cirrhosis. Transplant Proc. 2014;46(9):3114-3116.

42. Veldt BJ, Duarte-Rojo A, Thompson AJ, et al. Recipient IL28B polymorphism is an important independent predictor of posttransplant diabetes mellitus in liver transplant patients with chronic hepatitis C. Am J Transplant. 2012;12(3):737-744.

43. Kim YG, Ihm CG, Lee TW, et al. Association of genetic polymorphisms of interleukins with new-onset diabetes after transplantation in renal transplantation. Transplantation. 2012;93(9):900-907.

44. Jeong KH, Moon JY, Chung JH, Kim YH, Lee TW. Significant associations between CCL5 gene polymorphisms and post-transplantational diabetes mellitus in Korean renal allograft recipients. Am J Nephrol. 2010;32(4):356-361.

45. Nicoletto BB, Souza GC, Fonseca NK, et al. Association between $276 \mathrm{G} / \mathrm{T}$ adiponectin gene polymorphism and new-onset diabetes after kidney transplantation. Transplantation. 2013;96(12):1059-1064.

46. Dabrowska-Zamojcin E, Romanowski M, Dziedziejko V, et al. CCL2 gene polymorphism is associated with post-transplant diabetes mellitus. Int Immunopharmacol. 2016;32:62-65.

47. Romanowski M, Domanski L, Pawlik A, et al. Interleukin-17 gene polymorphisms in patients with post-transplant diabetes mellitus. Eur Rev Med Pharmacol Sci. 2015;19(17):3152-3156.

48. Chen QJ, Li J, Zuo SR, et al. Tacrolimus decreases insulin sensitivity without reducing fasting insulin concentration: a 2-year follow-up study in kidney transplant recipients. Ren Fail. 2015;37(4):601-606.

49. Kao CC, Lian JD, Chou MC, Chang HR, Yang SF. Tumor necrosis factor alpha promoter polymorphism in posttransplantation diabetes mellitus of renal transplant recipients. Transplant Proc. 2010;42(9):3559-3561.

50. Dutkiewicz G, Domanski L, Pawlik A, et al. Polymorphisms of superoxide dismutase, glutathione peroxidase and catalase genes in patients with post-transplant diabetes mellitus. Arch Med Res. 2010;41(5): 350-355.

51. Forgione MA, Weiss N, Heydrick S, et al. Cellular glutathione peroxidase deficiency and endothelial dysfunction. Am J Physiol Heart Circ Physiol. 2002;282(4):H1255-H1261. 
52. Hamanishi $\mathrm{T}$, Furuta $\mathrm{H}$, Kato $\mathrm{H}$, et al. Functional variants in the glutathione peroxidase-1 (GPx-1) gene are associated with increased intimamedia thickness of carotid arteries and risk of macrovascular diseases in Japanese type 2 diabetic patients. Diabetes. 2004;53(9):2455-2460.

53. Elens L, Sombogaard F, Hesselink DA, van Schaik RH, van Gelder T. Single-nucleotide polymorphisms in P450 oxidoreductase and peroxisome proliferator-activated receptor- $\alpha$ are associated with the development of new-onset diabetes after transplantation in kidney transplant recipients treated with tacrolimus. Pharmacogenet Genomics. 2013;23(12):649-657.

54. Kurzawski M, Malinowski D, Dziewanowski K, Droździk M. Impact of PPARA and POR polymorphisms on tacrolimus pharmacokinetics and new-onset diabetes in kidney transplant recipients. Pharmacogenet Genomics. 2014;24(8):397-400.

55. Gervasini G, Luna E, García-Cerrada M, García-Pino G, Cubero JJ. Risk factors for post-transplant diabetes mellitus in renal transplant: role of genetic variability in the CYP450-mediated arachidonic acid metabolism. Mol Cell Endocrinol. 2016;419:158-164.

56. Díaz-Molina B, Tavira B, Lambert JL, Bernardo MJ, Alvarez V, Coto E. Effect of CYP3A5, CYP3A4, and ABCB1 genotypes as determinants of tacrolimus dose and clinical outcomes after heart transplantation. Transplant Proc. 2012;44(9):2635-2638.

57. Kang ES, Kim MS, Kim CH, et al. Association of common type 2 diabetes risk gene variants and posttransplantation diabetes mellitus in renal allograft recipients in Korea. Transplantation. 2009;88(5):693-698.

58. Kurzawski M, Dziewanowski K, Łapczuk J, Wajda A, Droździk M. Analysis of common type 2 diabetes mellitus genetic risk factors in new-onset diabetes after transplantation in kidney transplant patients medicated with tacrolimus. Eur J Clin Pharmacol. 2012;68(12):1587-1594.

59. Gloyn AL, Pearson ER, Antcliff JF, et al. Activating mutations in the gene encoding the ATP-sensitive potassium-channel subunit Kir6.2 and permanent neonatal diabetes. $N$ Engl J Med. 2004;350(18):1838-1849.

60. Tarasov AI, Nicolson TJ, Riveline JP, et al. A rare mutation in ABCC8/ SUR1 leading to altered ATP-sensitive $\mathrm{K}+$ channel activity and beta-cell glucose sensing is associated with type 2 diabetes in adults. Diabetes. 2008;57(6):1595-1604.

61. Tavira B, Coto E, Torres A, et al; Pharmacogenetics of tacrolimus REDINREN study group. Association between a common KCNJ11 polymorphism (rs5219) and new-onset posttransplant diabetes in patients treated with Tacrolimus. Mol Genet Metab. 2012;105(3):525-527.

62. Parvizi Z, Azarpira N, Kohan L, Darai M, Kazemi K, Parvizi MM. Association between $\mathrm{E} 23 \mathrm{~K}$ variant in KCNJ11 gene and new-onset diabetes after liver transplantation. Mol Biol Rep. 2014;41(9):6063-6069.

63. Tavira B, Coto E, Díaz-Corte C, et al; Pharmacogenetics of Tacrolimus REDINREN Study Group. KCNQ1 gene variants and risk of newonset diabetes in tacrolimus-treated renal-transplanted patients. Clin Transplant. 2011;25(3):E284-E291.

64. Muscogiuri G, Chavez AO, Gastaldelli A, et al. The crosstalk between insulin and renin-angiotensin-aldosterone signaling systems and its effect on glucose metabolism and diabetes prevention. Curr Vasc Pharmacol. 2008;6(4):301-312.

65. Kurtz TW, Pravenec M. Antidiabetic mechanisms of angiotensinconverting enzyme inhibitors and angiotensin II receptor antagonists: Beyond the renin-angiotensin system. J Hypertens. 2004;22(12): 2253-2261.

Therapeutics and Clinical Risk Management

\section{Publish your work in this journal}

Therapeutics and Clinical Risk Management is an international, peerreviewed journal of clinical therapeutics and risk management, focusing on concise rapid reporting of clinical studies in all therapeutic areas, outcomes, safety, and programs for the effective, safe, and sustained use of medicines. This journal is indexed on PubMed Central, CAS,
66. Lee Sr, Moon JY, Lee SH, et al. Angiotensinogen polymorphisms and post-transplantation diabetes mellitus in Korean renal transplant subjects. Kidney Blood Press Res. 2013;37(2-3):95-102.

67. Özdemir BH, Özdemir FN, Ataç FB, Özdemir AA, Haberal M. Angiotensinogen $\mathrm{t} 235$ and angiotensin-converting enzyme insertion/deletion polymorphisms associated with the development of posttransplantation diabetes mellitus in renal allograft recipients. Transplant Proc. 2011;43(2):572-574

68. Horikawa Y, Oda N, Cox NJ, et al. Genetic variation in the gene encoding calpain-10 is associated with type 2 diabetes mellitus. Nat Genet. 2000;26(2):163-175.

69. Baier LJ, Permana PA, Yang X, et al. A calpain-10 gene polymorphism is associated with reduced muscle mRNA levels and insulin resistance. J Clin Invest. 2000;106(7):R69-R73.

70. Kurzawski M, Dziewanowski K, Kedzierska K, Gornik W, Banas A, Drozdzik M. Association of calpain-10 gene polymorphism and posttransplant diabetes mellitus in kidney transplant patients medicated with tacrolimus. Pharmacogenomics J. 2010;10(2):120-125.

71. Szuszkiewicz M, Bell J, Vazquez M, et al. ENPP1/PC-1 K121Q and other predictors of posttransplant diabetes. Metab Syndr Relat Disord. 2011;9(1):25-29.

72. Ergün I, Keven K, Sengül S, et al. Endothelial nitric oxide synthase gene intron 4 polymorphism predicts new onset diabetes mellitus after transplantation in kidney allograft recipients treated with cyclosporin A. Int Urol Nephrol. 2011;43(2):543-548.

73. Vattam KK, Khan IA, Movva S, et al. IGF2 ApaI A/G polymorphism evaluated in ESRD individuals as a biomarker to identify patients with new onset diabetes mellitus after renal transplant in Asian Indians. Open J Nephrol. 2013;3:104-108.

74. Kang ES, Magkos F, Kim BS, et al. Variants of the adiponectin and adiponectin receptor-1 genes and posttransplantation diabetes mellitus in renal allograft recipients. J Clin Endocrinol Metab. 2012;97(1): E129-E135.

75. Yao B, Chen X, Shen FX, et al. The incidence of posttransplantation diabetes mellitus during follow-up in kidney transplant recipients and relationship to Fok1 vitamin D receptor polymorphism. Transplant Proc. 2013;45(1):194-196.

76. Romanowski M, Dziedziejko V, Maciejewska-Karlowska A, et al. Adiponectin and leptin gene polymorphisms in patients with posttransplant diabetes mellitus. Pharmacogenomics. 2015;16(11): 1243-1251.

77. Yu AR, Xin $\mathrm{HW}, \mathrm{Wu} \mathrm{XC}$, et al. Adiponectin gene polymorphisms are associated with posttransplantation diabetes mellitus in Chinese renal allograft recipients. Transplant Proc. 2011;43(5):1607-1611.

78. Chang HR, Yang SF, Tsai JP, et al. Plasminogen activator inhibitor-1 $5 \mathrm{G} / 5 \mathrm{G}$ genotype is a protecting factor preventing posttransplant diabetes mellitus. Clin Chim Acta. 2011;412(3-4):322-326.

79. Wang $\mathrm{P}$, Hudspeth E. Increased body mass index but not common vitamin D receptor, peroxisome proliferator-activated receptor $\gamma$, or cytokine polymorphisms confers predisposition to posttransplant diabetes. Arch Pathol Lab Med. 2011;135(12):1581-1584.

\section{Dovepress}

EMBase, Scopus and the Elsevier Bibliographic databases. The manuscript management system is completely online and includes a very quick and fair peer-review system, which is all easy to use. Visit http://www.dovepress.com/testimonials.php to read real quotes from published authors. 